\title{
The Influence of Jan Tinbergen on Dutch Economic Policy
}

\author{
F. J. H. Don ${ }^{1}$ (D) \\ Published online: 11 February 2019 \\ () The Author(s) 2019
}

\begin{abstract}
From the mid-1920s to the early 1960s, Jan Tinbergen was actively engaged in discussions about Dutch economic policy. He was the first director of the Central Planning Bureau, from 1945 to 1955. It took quite some time and effort to find an effective role for this Bureau vis-à-vis the political decision makers in the REA, a subgroup of the Council of Ministers. Partly as a result of that, Tinbergen's direct influence on Dutch (macro)economic policy appears to have been rather small until 1950. In that year two new advisory bodies were established, the Social and Economic Council (SER) and the Central Economic Committee. Tinbergen was an influential member of both, which effectively raised his impact on economic policy. In the early fifties he played an important role in shaping the Dutch consensus economy. In addition, his indirect influence has been substantial, as the methods and tools that he developed gained widespread acceptance in the Netherlands and in many other countries.
\end{abstract}

Keywords Consensus economy · Macroeconomic policy · Planning · Policy advice · Tinbergen

JEL Classification $\mathrm{E} 600 \cdot \mathrm{E} 610 \cdot \mathrm{N} 140$

The author is a former director of the CPB (1994-2006). He is grateful to Peter van den Berg, André de Jong, Kees van Paridon, Jarig van Sinderen and Bas ter Weel for their comments on earlier drafts. André de Jong also kindly granted access to several documents from his private archive, largely stemming from CPB sources.

\section{F. J. H. Don}

henk.don@acm.nl

1 Authority for Consumers and Markets, P.O. Box 16326, 2500 BH The Hague, The Netherlands 


\section{Introduction}

Fifty years ago, in 1969, the first Nobel Prize in economics ${ }^{1}$ was awarded to Ragnar Frisch and Jan Tinbergen for having developed and applied dynamic models for the analysis of economic processes. In his presentation speech, Erik Lundberg of the Royal Swedish Academy of Sciences explained:

Both our laureates have made fundamental analysis of the theoretical basis of rational decision-making in the field of economic policy. (...) Professor Tinbergen, with the support of theories previously put forward by Frisch, has developed a simplified system for economic policy that has been applied in Holland. (...) As head of the Central Planning Bureau in the Hague, Professor Tinbergen and his co-workers have constructed an econometric model for forecasting and planning economic policy in Holland (Lundberg 1969).

While Tinbergen's contributions to the theory of economic policy and to the art of building and applying econometric models are well known and undisputed, it has been less clear what influence he has had on actual policy making. Yet the motivation for his work was a strong desire to improve economic policies. The present contribution intends to assess what influence Jan Tinbergen has had on Dutch economic policy, with a strong focus on macroeconomic policy.

Retracing the history of Tinbergen's contributions to the policy debate and of the actual policy decisions made, we can derive when his ideas are likely to have had a direct influence on policy decisions. This derivation will always carry some degree of uncertainty, because it is almost impossible to establish a direct relationship between the policy decisions and the contributions made by Tinbergen. And, of course, the ideas brought forward by Tinbergen often were the result of exchanges with political friends and professional colleagues. In particular in the period 1945-1955, his input to the policy debate was often derived from the analyses of and discussions with the group of skilful people he had managed to assemble at the Central Planning Bureau (CPB). ${ }^{2}$ These caveats should be observed throughout this assessment.

The exposition is structured in chronological order. Section 2 starts with Tinbergen's contributions to the political debate before and during the Second World War. Sections 3 and 4 discuss the period 1945-1955, when he was the first director of the CPB. Section 3 roughly covers the first half of that decade, when the CPB had to find its place in the policy making community. Section 4 covers the second half, when this community was enlarged with the Social and Economic Council (SER) and the Central Economic Committee (CEC) in 1950. Section 4 also includes some observations on Tinbergen's work for the SER after 1955. Section 5 concludes with an assessment of the influence that Tinbergen has had on Dutch economic policy with the work he did from the mid-1920s to the early 1960s.

\footnotetext{
1 To be precise: the first Bank of Sweden's Prize in Economic Science dedicated to the memory of Alfred Nobel.

${ }^{2}$ In English the CPB is currently referred to as the CPB Netherlands Bureau for Economic Policy Analysis. Here I will stick to the name "Central Planning Bureau", which was used until the mid-1990s.
} 
In 1952-1953 Tinbergen was increasingly involved in theoretical work and considered moving back to academia. In addition, his visit to India in 1951 made him realize that much bigger economic problems had to be solved in other parts of the world. He left the CPB in the Summer of 1955 to focus on development planning (Magnus and Morgan 1987, p. 134; Duyf 1993, pp. 17-19; Jolink 2003, pp. 240, 252-255; Pen 2013, p. 129). He continued to be a member of the SER until 1962. That marked the end of his direct involvement with Dutch economic policy.

\section{Tinbergen's Contributions Before 1945}

\subsection{From Physics to Economics}

Born in 1903 in The Hague, in his youth Jan Tinbergen learned about the atrocities of the First World War and the poverty and unemployment in those times. In 1922 he and his lifelong companion Tine de Wit joined the Social Democratic Labour Party. It was their intention to dedicate their lives to the goals of the social democratic movement. As a student of physics in Leiden, he tried to apply the tools of mathematics and physics to economic problems. He was convinced that such a scientific approach was required to successfully implement the socialist agenda. In 1923, he co-founded a Leiden section of the Social Democratic Students Club. He published his ideas in the Club's journal Kentering and became one of its co-editors in 1925. The ideas ranged from the need to study economic relationships and to apply mathematics as the obvious tool, to issues of socialisation, industrial organisation and competition. Tinbergen considered economic competition to be the major characteristic of a capitalist society. To get a thorough understanding, he took up serious theoretical and empirical studies of market structure and price formation, building in particular on the work of Cournot. The study of price dynamics brought him to business cycle research. This became his assignment at the Dutch Central Bureau of Statistics (CBS) ${ }^{3}$ after he was hired there in 1927 (Jolink 2003, Chapter 2).

At the CBS, Tinbergen contributed to business cycle theory and its statistical applications. In addition, he embarked on empirical studies of dynamics in specific markets, ranging from potato flour to ship building. In the course of this work, Tinbergen developed ideas similar to the 1961 rational expectation hypothesis of Muth (Keuzenkamp 1991). After the 1929 stock exchange crash, the issue of unemployment came high on the agenda. Tinbergen was not afraid to stand up against the socialist claim that increasing wages would be the appropriate measure to fight the crisis. From 1928, he wrote regularly on business cycle analysis and unemployment for De Socialistische Gids, in 1930-1939 as one of its editors (Boumans 1989, p. 233). And he started a new line of research to study the dynamic relationship between unemployment and wages, which led him to look into the more structural movements of economic phenomena (Jolink 2003, Chapter 3).

\footnotetext{
3 Currently referred to in English as Statistics Netherlands.
} 


\subsection{On Planning}

Next to his work for the CBS, Tinbergen continued to take up more political work. In 1932 he wrote a letter to F. M. Wibaut, an influential socialist politician and Amsterdam alderman. In this letter Tinbergen asked for comments on a provisional summary of a study on the planning of economic reforms. He had started this study together with two fellow party members. The letter led to an intensive collaboration between Tinbergen and Wibaut. The result was a study on worldwide planning of production, published as Wibaut (1934). Its political impact however, was negligible (Jolink 2003, pp. 105-128).

In a keynote address to the 1932 annual meeting of the Dutch Economic Association, Tinbergen claimed that optimum economic results required government regulation to coordinate private production [Tinbergen (1932), summarized in Knoester and Wellink (1993, pp. 19-20)]. This outline for a planned economy also proved unsuccessful (Jolink 2003, pp. 129-130). However, De Man (1934) produced a socialist Labour Plan for Belgium, aiming to mobilize labour to participate more actively in economic life, for example through large public works. This example provided inspiration for a study group of the Social Democratic Labour Party which included Jan Tinbergen and Hein Vos. The party leaders decided to prepare a Dutch Labour Plan, which was published in 1935 (SDAP 1935).

Jolink (2003, pp. 130-135) has concluded that Tinbergen's direct influence on this Labour Plan was close to zero and that his indirect influence was limited. It is true that his pleas for the introduction of a basic income were ignored and the choice for a national plan was stressed in spite of Tinbergen's conviction that international planning was the proper way. Nevertheless, according to Boumans (1989, p. 236) the Plan showed remarkable similarities with Tinbergen's publications in the two preceding years and Van der Linden (1985, pp. 32-38) observed that the Plan included innovative proposals for anticyclical policies based on statistical data. Also, Tinbergen managed to insert some quantitative empirical knowledge into the policy proposals. Indeed Passenier (1994, pp. 23-25) has noted that the Plan had a clear quantitative economic basis and contained lines of reasoning that would later form the fundament for the macroeconomic models of the CPB. And Jolink (2003, p. 134) mentions that, in retrospect, Hein Vos indicated that the relative success of the Plan was due to its statistical foundation.

Whether or not he had had much influence on its contents, Tinbergen supported the Plan and his reputation inside and outside the Party was already such that his name gave the Plan a respectable status. As for its political impact, the Plan contained proposals for an institutional setup which looks like what would be created after 1945 with the Central Planning Bureau and the Social and Economic Council (see below). Back in 1935, the Plan was recognized as a constructive step away from ideology. In spite of that, its interventionist policy proposals received little support from the other political parties (Passenier 1994, pp. 25-27; Jolink 2003, p. 132). 


\subsection{Policy Analysis and Advice}

In 1936, Tinbergen again presented a keynote address to the annual meeting of the Dutch Economic Association. This time, the question to be discussed was whether economic improvement was possible without an improvement in the export position; and what could be learned from foreign experience. To provide an answer, Tinbergen presented the results of a macroeconomic model which he had built [Tinbergen (1936), published in English as Tinbergen (1959a)]. That model is generally considered the first econometric macro-model in the world. His conclusion was that economic improvement was indeed possible and that, amongst the policy measures that had been suggested, the best options were a number of policy measures proposed in the Labour Plan and in particular a devaluation of the Dutch guilder (Tinbergen in Magnus and Morgan 1987, pp. 122-123; Knoester and Wellink 1993, p. 14; Jolink 2003, pp. 135-136).

This work was in many ways new and revolutionary to the profession. Knoester and Wellink (1993, pp. 11-19) extensively describe and analyse the discussion that followed the address in the meeting of the Association. Like De Wolff and Van der Linden (1988, pp. 313-314), they conclude that it was received with a mixture of suspicion and puzzlement. But they also show how various members of the Association, in their initial reactions, already pointed to several pitfalls in economic modelling and to the limitations of economic models. In particular, they raised the issues of causality, interdependency, the reliability of coefficients that provided the best fit to the available observations and the validity of the model for forecasting or for analysing future policy effects. Of course several of these issues would later be taken up by the Cowles Commission (see e.g. Christ 1994). It should also be mentioned that some members at the meeting expressed their admiration for the skill and daring shown by Tinbergen in building a mathematical model based on empirical data and applying it to questions of economic policy. Indeed one member expected that this work would open up a new and broad field of research, which was bound to yield many benefits in future years.

In any case, the Dutch government had already decided for a devaluation of the guilder a month before the meeting (De Roos 1987, p. 125). It seems unlikely ${ }^{4}$ that Tinbergen's advice has had a real impact on that decision, which was also Tinbergen's own assessment in Magnus and Morgan (1987, p. 123).

In September 1936, Tinbergen started working for the League of Nations in Geneva. After Gottfried von Haberler had produced a review of business cycle theories, Tinbergen's assignment was to perform statistical testing of these theories. Tinbergen claimed that the task of the statistician was not only to investigate the relative influence of different theoretical explanations of economic phenomena, i.e. business cycles, but also to provide recommendations to governments for efficient (business cycle) policies. Because his interest in policy issues caused some discomfort for his employer, the latter decided to engage Dennis Robertson as an advisor to the project.

\footnotetext{
${ }^{4}$ But not impossible. According to Duyf (1993, p. 13), the advisory reports for the annual meeting were published just before the devaluation.
} 
Though Robertson did not have much impact on Tinbergen's actual work, policy recommendations proved to be beyond the scope of what Tinbergen managed to do before his contract ended in September 1938 (Jolink 2003, pp. 170-184).

During his stay in Geneva, Tinbergen paid quarterly visits to the CBS in order to continue coordinating the activities of its business cycle department (Duyf 1993, p. 13). And after his return in the Netherlands, he stayed with the CBS until after the war. During the war, when the Netherlands was occupied by the Nazi regime (May 1940-May 1945), he wrote several papers and books on economics and econometrics. Also, he studied the likely economic consequences of the war and he was engaged in discussions about the post-war challenges, e.g. in the (secret) Van Asbeck committee (Jolink 2003, Chapter 6). For the present purpose, the following publications should be mentioned. First, a secret CBS memorandum dated April 1943, entitled 'About the organisation of statistical research for controlling the business cycle'. This contained a design for a Bureau for Economic and Statistical Research to be established after the war, which would analyse economic interdependencies and provide advice to the government on anti-cyclical policy (Passenier 1994, pp. 30-32). Second, an August 1944 CBS memorandum on 'National bookkeeping, goals, problems and results' that would serve as the basis for the first post-war national recovery plan (Jolink 2003, p. 217). Third, a book about the lessons to be learned from the past 30 years, including an assessment of the social and economic consequences of the two world wars (Tinbergen 1944; cf. Jolink 2003, pp. 227, 229). And finally, Tinbergen's assessment for the Van Asbeck committee, inspired by Keynes, stating that it would be better to write off the losses incurred in the war than to concentrate on how to recoup compensation for the damage (published as Tinbergen 1946a; cf. Jolink 2003, pp. 230-231).

\subsection{The Lesson of Thirty Years}

It is useful to highlight the main ideas that Tinbergen brought together in his book "De les van dertig jaar" (The lesson of thirty years), Tinbergen (1944). ${ }^{5}$ We will see how several of these ideas recurred in his contributions in the next decade. This source clearly shows them to be Tinbergen's own ideas, of course formed in his studies and exchanges in the preceding years. He distinguished five issues that need attention:

1. how the economy is organized;

2. what the equilibrium position and long term development (trend movement) should be;

3. measures with respect to disturbances (affecting the cyclical movement);

4. the interrelations between the national economies; and

5. measures required in the transition period immediately after the war.

\footnotetext{
5 The preface to the second edition (1946, page XI) mentions that the first edition was printed during the period of occupation, with the intention to publish after the liberation. It also records some updates of the text.
} 
As a reference for what follows, let me summarize Tinbergen's position on these five issues, as exposed in Tinbergen (1944).

As for (1), the organisation of the economy, with some exceptions Tinbergen clearly opted for (i) private ownership of the means of production and freedom for entrepreneurs within a system of social legislation and income taxes; (ii) corporate coordination on standards and efficiency; (iii) some government stimulus for (innovative) investments; and (iv) government instruments for countercyclical policies.

In relation to (2), the targets were: (i) full employment of labour and capital; (ii) equilibrium on the current account of the balance of payments; and (iii) a more just distribution of net incomes which leaves sufficient incentives for improving productive efficiency. Tinbergen believed that wage formation should not be left to a power struggle but to a system of consultations, supervised by a central wage council.

After the strong cyclical movements between 1919 and 1939, Tinbergen considered anticyclical policies (issue 3 ) to be a very important element of macroeconomic policy. Based on sound statistical information about the economic situation, in his view government expenditures should be set at such a level that total demand will lead to full employment. When required, more indirect stabilizing measures may help to target threats of disequilibrium in particular areas.

According to Tinbergen, international economic relations (issue 4) should move towards removing the impediments to trade. Also capital movements should be resumed on a large scale in order to reduce the large differences in prosperity between nations. International bodies should warrant free trade and equilibrium on current accounts.

Finally, on issue (5), Tinbergen considered that immediately after the war special measures would be required such as repairing the worst damage, maintaining employment in the transition period and temporarily maintaining the system of distribution and price control. A property tax should help the necessary financial reform. The period of reconstruction would necessarily be characterized by a constrained level of consumption. Proper anticyclical policies should avoid a period of crisis and stagnation like the one that had been experienced after the First World War.

\subsection{Evaluation 1922-1945}

From the start, it was Tinbergen's ambition to help reach the goals of the social democratic movement by applying a scientific approach to economic problems. He embarked on this agenda with remarkable creativity and perseverance. Early disappointments in trying to define a realistic concept of economic planning did not stop him. His support for the 1935 Dutch Labour Plan enhanced its quality and credibility, although his real influence on this Plan may have been relatively small.

From 1927 onwards, Tinbergen performed his economic research at the CBS, focussing on business cycles. This led him to the construction, in 1936, of a macroeconomic model for the Dutch economy, which he employed for analysing the likely effects of different policy measures aimed at improving the economic situation. This 
work is unlikely to have had a real direct influence on economic policy, but it was a major step forward for the economics profession and for his own agenda.

In 1937-1945, along with his work for the League of Nations, the CBS and the Van Asbeck committee, Tinbergen deepened his knowledge of economic interdependencies and further shaped his ideas on methods and institutions for the coordination of economic policies. Much of this came together in his 1944 book 'The lesson of thirty years', in which he took well-argued positions on a range of important economic issues. These positions, summarized in Sect. 2.4 above, were the starting point for his more influential work in the next decade.

\section{The First Years of the Central Planning Bureau}

\subsection{Establishment of the CPB and the Plan for 1946}

The first Dutch Cabinet of Ministers after the war was installed in June 1945 by Queen Wilhelmina. The new prime minister, Schermerhorn, addressed the people in a radio speech on June 27. In this speech he stated that recovery and reconstruction of Dutch productive capacity could only be effectively pursued on the basis of a general social economic-financial plan, which would contain guidelines for government policy. Following directions from the Council of Ministers, a newly created scientific bureau should prepare such a plan. The new minister of Trade and Industry, the socialist Hein Vos who had been the leading author of the 1935 Labour Plan, asked his friend Jan Tinbergen to set up this Central Planning Bureau (CPB). The CPB was allowed to start its work in September 1945, in anticipation of a legal basis which would only follow in 1947 (Van Cleeff 1970, pp. 12-13; Maas 1986, p. 1; Passenier 1994, pp. 34, 37-40; Jolink 2003, pp. 233-236).

Tinbergen quickly formed a team and drafted the first version ${ }^{6}$ of a Plan for 1946, which included some preliminary estimates for further recovery in 1947-1950. In February 1946 an extract was discussed in the ministerial Council for Economic Affairs (REA). ${ }^{7}$ It soon became clear that the draft Plan was not only based on (scarcely available) data and estimates, but also on hopes and desires which had only been globally checked for feasibility. The REA concluded that the CPB should be better informed by the ministries and by the organized industries, in order to improve the quality of the Plan. The REA hardly discussed the content matter of the Plan and Tinbergen did not receive any directions for the next draft. There was a discussion on whether this draft could be published. Tinbergen and Vos thought this would be helpful in gaining support for a policy of sobriety, but the other ministers held a rather different view. Prime minister Schermerhorn made it clear that a

\footnotetext{
${ }^{6}$ In the early years, the CPB prepared consecutive drafts of what it called the first, second etc. memorandum on the respective Plan; I will refer to all preliminary versions as draft Plans.

7 The REA was one of the new subgroups of the Council of Ministers, focussing on economic issues. Initially its meetings were held every week and they could be attended by the President of the Central Bank, the Director of the CPB and some high ranking officials from the relevant ministries.
} 
plan could only be published after the necessary policy decisions would have been taken. Therefore, preliminary considerations which precede the decisions could not be published (Duynstee and Bosmans 1977, pp. 494-495; Maas 1986, pp. 13-14; Passenier 1994, pp. 82-83).

Almost 2 weeks after the general elections of May 17, 1946, the now outgoing ministers in the REA discussed a second draft of the 1946 Plan. This version was not much different from the first. Again the discussion focussed on the issue of publication. Now prime minister Schermerhorn was willing to allow publication, provided that it would be made clear that only the $\mathrm{CPB}$ was responsible for its contents and that it did not reflect government decisions on policy. This was agreed. While Tinbergen (and Vos) had hoped that the Plan would have been accepted as the basis for policy, the REA expressly distanced itself from it. Not only because the statistical basis was necessarily weak, but clearly the majority in the REA was not willing to accept it as a point of departure for government policy (Duynstee and Bosmans 1977, pp. 495-496; Maas 1986, pp. 14-15; Passenier 1994, pp. 83-84).

Meanwhile, Vos had prepared a draft law to formally establish the CPB and its tasks. This draft was sent to parliament in March 1946. It gave the CPB an important role in coordinating the activities of different government bodies and in systematically guiding private industry. While strong government interference with private industry immediately after the war was widely accepted, Vos maintained that central planning would continue to be required, in order to protect the population and the business community against disturbances of the equilibrium in the economic system. This view met with strong criticism in and outside parliament and the draft law had to wait for the next government (Van Cleeff 1970, pp. 14-16; Duynstee and Bosmans 1977, pp. 496-500; Van der Linden 1985, pp. 180-185; Maas 1986, pp. 10-11; Passenier 1994, pp. 41-43).

In contrast with a NIPO poll made 3 months before, the general elections of May 1946 resulted in a majority for the Christian-Democratic parties, while the Labour party did not manage to become the largest (De Liagre Böhl et al. 1981, pp. 39-40). The new Cabinet presented itself on July 5, 1946 and stated that it would forcefully lead the recovery of prosperity, informed by the preparations and advice of a planning bureau and in close consultation with parliament. It would also foster the self-activity of individuals and groups. This would then allow a strong reduction of government intervention. Soon after this presentation, Tinbergen submitted a set of proposals to the new Council of Ministers. ${ }^{8}$ His aim was to improve the work and position of the $\mathrm{CPB}$, in line with the Explanatory Memorandum of the draft law and leaving the final decision on the Plan to the Council of Ministers. In its meeting on July 30, the REA decided to broadly accept these proposals. It seemed that a step forward had been set, increasing the influence of Tinbergen and his CPB. Yet,

\footnotetext{
${ }^{8}$ In a letter dated July 15, 1946 (Tinbergen 1946b). Passenier (1994, p. 83) mentions a similar letter that he would have written in April 1946, but apparently he refers to the same letter.
} 
the new minister of Economic Affairs, Huysmans, told Tinbergen that the proposals should have been addressed to him and that the position of the CPB would soon be decided in the new law. In line with the earlier statement of the new prime minister Beel, Huysmans also made it clear that the Bureau would only have an advisory role (Maas 1986, pp. 16-18). This was also Huysmans' line later, when parliament resumed the debate on the law that would formally establish the CPB. In the phase of economic recovery the $\mathrm{CPB}$ would prepare guidelines, but after that phase it would only assess future developments. This approach was accepted in parliament, and the law that formally established the CPB came into force on April 21, 1947 (Van Cleeff 1970, pp. 16-18; Van der Linden 1985, pp. 186-195; Passenier 1994, pp. 42-45). ${ }^{9}$

Views differ as to whether the political debate on the task of the CPB had a strong impact on the CPB's actual work at the time. According to De Wolff and Van der Linden (1988, p. 318), "this revision of the tasks of the Planning Office did not really much matter. The entire life of the country was controlled by a detailed rationing system". But according to Jolink (2003, p. 241), Tinbergen changed his course when he felt the CPB would be put at risk if he would continue to follow the socialist planning ideas of Vos and himself. I very much doubt this. The views that Tinbergen had set out in his 1944 book (summarized in Sect. 2.4 above) suggest that he no longer shared the socialist planning ideas of Vos (see also Tinbergen in Magnus and Morgan 1987, p. 132; Boumans 1989, p. 237). Planning of production, as was the aim in Tinbergen (1932), had been replaced by planning of economic policies, in particular of anticyclical policies (Tinbergen 1944; see also Tinbergen 1959b). Rather, the effect of the political debate should be reflected in the position of the CPB, whether it would be a coordinator of policies or an advisor to the government. And here we observe that the advisory role already was much closer to reality than the coordination role.

Looking back in 1987-1988, Tinbergen remembered that, for a long time, he had preferred a CPB which would not only explore possibilities but also express preferences, scientifically derived from the maximization of the prosperity of the population. But he was disappointed by the general lack of interest in the views of the CPB on the choice of policies (De Jong et al. 1988, p. 654; cf. also Magnus and Morgan 1987, pp. 132-133). In a 1964 book explaining a system of central planning, he stated that "( $\mathrm{t}$ )he products of a CPB are essentially recommendations to the government" (Tinbergen 1964, p. 7). And in 1970 he writes that he considered it a mistake that in many Plans too few alternatives for targets had been analysed, and hence also for instruments. He added that also the members of parliament could have pressed harder for such information (Tinbergen 1970, p. 26).

\footnotetext{
${ }^{9}$ Remarkably, the Law itself was hardly changed. Article 3 sub 1 and 2 still stated: "The task of the Central Planning Bureau is (...) to prepare a Central Economic Plan which at regular times shall be laid down by the Government for the benefit of the coordination of the Government's policy in the economic, social and financial fields, as well as the submission of recommendations on general questions which may arise with respect to the realization of the plan. The Central Economic Plan is a balanced system of estimates and directives with regard to the Netherlands economy" (quoted from the translation provided in Central Planning Bureau (1956), Appendix I).
} 
In any case, the new Cabinet did not follow the course that Tinbergen had asked for in his letter of July 1946. The third draft of the Plan 1946 was discussed in the REA meeting of September 10, 1946. It provided much more detail, although the CPB still had to cope with a lack of accurate data. The Plan now contained a bottom-up approach that started at the level of branches of industry. According to the $\mathrm{CPB}$, the general shortage of energy and foreign currency called for central allocation. In particular, it proposed to allocate energy according to the amount of foreign currency that it would generate in different industries. This crucial policy rule was rejected by the REA because it was considered to be possibly harmful to domestic recovery and welfare. All other policy proposals were left without guidance (Maas 1986, pp. 18-19).

\subsection{Planning for 1947 and 1948; the Marshall Plan}

In the same meeting of September 10, 1946, the REA discussed the first draft of the Plan for 1947, which included a Frame Plan for the period up to 1952. Tinbergen had prepared a list of subjects to be decided upon, in order to enable him to prepare the second draft. In addition, he proposed that the government would send the first draft to parliament. Instead, the REA decided that the CPB would send it to parliament, accompanied by a note from the government stating that the main figures and conclusions of this Plan, for the time being, would be the starting-point for its economic, social and financial policies (Maas 1986, pp. 19-22; Passenier 1994, p. 84). While this was more than Tinbergen managed to obtain before, it was not the discussion and full support that he had aimed for.

In June 1947, the CPB had completed the second draft of the Plan for 1947. It was a much more detailed version, based on data and plans supplied by the ministries, which in turn relied on data from the various branches of industry. Huysmans and Tinbergen proposed to publish this draft without further discussion. But the REA decided that the ministries would get prior opportunity to comment, after which an adjusted draft should again be submitted to the REA. In the end, the REA never discussed a later draft. And the second draft was never published, although it received some confidential circulation in February 1948 (Maas 1986, pp. 23-24).

In contrast to the Plan for 1947, the first draft of the Plan for 1948 did generate some discussion on economics in the REA on August 22, 1947. Now the CPB had prepared several alternatives, in particular for the growth in exports and the remaining need for foreign credit and sale of foreign assets in order to fund the necessary imports. The views on what would be a realistic amount of foreign credit differed between the ministers of Finance (Lieftinck) and Economic Affairs (Huysmans). This discussion in itself was a step forward, but it also meant yet another ban on publication (Maas 1986, pp. 24-25).

Meanwhile a new source of foreign currency was being discussed in Paris. Here, sixteen European countries negotiated the terms for receiving financial aid from the United States, following an initiative announced in June 1947 by George Marshall, then the US Secretary of State. Such aid would alleviate a major restriction 
on economic recovery and growth that the European countries were facing, namely the lack of resources to finance the necessary imports. The European Recovery Plan, often referred to as the Marshall Plan, required each participating country to produce a survey of its economic situation and a specification of the aid required (Maas 1986, p. 28; Passenier 1994, p. 53).

Hirschfeld was appointed as Government Commissioner in charge of the negotiations for the Netherlands. On September 22, 1947 the sixteen countries reported their assessments to the US officials, Hirschfeld reporting on behalf of The Netherlands. The REA was surprised that the figures that he presented for the Dutch economy had not been submitted to the REA nor checked with the CPB. But to avoid confusion in the negotiations, the CPB was not allowed to publish its new estimates for 1948. These estimates had been produced in October 1947, based on more recent data. They included a more pessimistic assessment of the shortage for foreign currency (Maas 1986, pp. 34-35, 37; Passenier 1994, p. 88). To indicate the size of the problem, the shortage was estimated to be in the order of $10 \%$ of National Income.

The October 1947 version of the Plan for 1948 offered three alternative scenarios based on different assumptions for the amount of Marshall funds that would become available. For the two scenarios in which these funds would be insufficient, the CPB suggested various policy measures to curtail domestic expenditures. These suggestions were largely ignored until the REA meeting of November 26, 1947. In this meeting the minister of Finance, Lieftinck, called for a curtailment of domestic consumption and investment in order to reduce the need for foreign currency. Marshall funds were unlikely to become available before the Summer of 1948. Not all ministers were convinced that such measures would be required. As a compromise, the REA decided that the Foreign Currency Commission, in which the CPB had a representative, would prepare a proposal for a curtailment package. The political debate continued for several months. Curtailment measures for the first quarter of 1948 were probably based on an assessment of the ministry of Finance. That assessment was more pessimistic than the one of CPB. The CPB assessment was accepted as a compromise for the second quarter of 1948 (Maas 1986, pp. 30-40).

In July 1948 the REA even ordered the CPB to prepare a plan for the allocation of the Marshall funds, in cooperation with the Dutch Central Bank and with an official from the ministry of Economic Affairs. Thus it recognized the value of the CPB in the preparation of policy measures, though of course the decisions would be made by the ministers (Maas 1986, p. 40).

\subsection{Planning for 1949 and 1950; New Procedures}

Tinbergen continued to bring various proposals to the politicians. In June 1948 he wrote a letter to Van den Brink (who had succeeded Huysmans as minister of Economic Affairs), stressing the need to raise the investment level in manufacturing and proposing some economic policy measures. Also, he suggested that these measures could be further discussed in a study committee formed by the relevant ministries. Two months later, the first draft of the Plan for 1949 was completed. This draft also criticized the choice made in priorities between consumption and investment. 
Neither document was discussed in the REA. It took until January 1949 before the REA finally discussed the issue and decided to delegate the question of restraining consumption to a working committee (Maas 1986, pp. 43-45).

In February 1949, a revised version of draft Plan for 1949 showed that under current policies several problems would emerge. In particular, the level of national production would not be high enough to cover the domestic needs. The result would be a major deficit on the current account of the balance of payments. Against this background, the draft Plan proposed a number of targets for economic policy and discussed various measures to reach these targets. This resulted in the advice to restrain consumption and to create more room and stimulus for investment in the manufacturing industry. In addition, the draft Plan contained a plea for closer coordination of trade policy with general economic policy, to support the priority for imports of investment goods. In the REA meeting at the end of March, Tinbergen proposed to publish this Plan and expressed his hope that the REA would accept it as a guideline for economic policy. However, publication was refused, notably because the text was critical of government policy. Subsequently, a third version of the Plan 1949 was finally accepted for publication in May 1949, but only with the status of an advice under responsibility of the CPB and with several amendments to avoid some disputed assessments and explicit tensions with current policies (Maas 1986, pp. 45-50; Passenier 1994, pp. 89-90).

In an effort to clarify what was expected from the $\mathrm{CPB}$, minister van den Brink introduced a procedure which started from instructions defining the targets for a new Plan. These should then define the framework for the policy advice by the CPB. The instructions for the preparation of the Plan for 1950 were agreed in the REA in June 1949, adding a number of policy measures that were already decided upon. Because now the targets were already set, the discussion of the first draft plan for 1950 in early September 1949 focussed on the economic analysis and on the merits of the policy proposals that the CPB brought forward. Views differed, in particular on the strength of foreign demand and on the value of the instruments of wage restraint and devaluation (Maas 1986, pp. 50-54; Passenier 1994, p. 91).

Later in September 1949, the United Kingdom decided for a devaluation of the Pound, and the Netherlands soon followed suit. Hence the second draft of the Plan for 1950 included an analysis of the effects of this devaluation, which was strongly debated in the REA meeting of January 11, 1950. In the following weeks, the discussion moved to the merits of various policy measures suggested by the CPB, which ranged from consumption restraint to wage differentiation and tax policies. In the end, only a few relatively minor measures were accepted. More than its predecessors, the final Plan 1950 reflected actual government policies (Maas 1986, pp. 54-58; Passenier 1994, pp. 91-92).

For some time the CPB had also been working on an assessment of the medium term prospects and policies required to attain equilibrium on the balance of payments, a high level of employment and a satisfactory level of consumption. This 'Structuurnota' appears to have been useful in providing information to the ministry of Economic Affairs for its industrialisation policy 
(Passenier 1994, pp. 90-91). A short version was discussed in the REA in March 1950. This discussion focussed on the target for the balance of payments and (again) on the merits of devaluation, consumption restraint and tax measures. The REA disagreed with the more activist attitude towards private investment that the CPB proposed (Maas 1986, pp. 58-62). The discussion did not have an impact on actual economic policy. Indeed, as is apparent from De Liagre Böhl et al. (1981), the CPB was almost absent in the debate about the policy for industrialisation. Yet, in the 1947 meeting of the Dutch Economic Association, Tinbergen made some comments on the proposals of Kohnstamm, a former government official, followed by an article in a Dutch economics journal (De Liagre Böhl et al. 1981, pp. 196-212).

\subsection{Evaluation 1945-1950}

Overall, these first years of the CPB do not show much direct influence of Tinbergen or the CPB on Dutch economic policy. While Tinbergen tried to get either support for his Plans or instructions on how to amend them, he got neither. Indeed, in the first few years the debate hardly moved beyond the question whether publication was allowed and if so, what could be published. Perhaps Tinbergen's attitude played a role here. As he explained later, he still felt quite young at the time and did not consider himself to be the right person to point out his usefulness to people much older than him (De Jong et al. 1988, pp. 654-655). Also, he felt that the services of the CPB "should be demanded, rather than offered and that, in order to be in demand, their usefulness had to be proved by their quality" [Tinbergen (1952a, p. 7); also mentioned by him in De Jong et al. (1988, p. 654)]. Other observers have brought forward different explanations: a general culture of respect for political power, a divide between the world of politics and the world of science, a lack of interest among the politicians for the detailed economic analysis, or a flaw in the institutional setup showing a lack of political will (Passenier 1994, pp. 85-86). Also the socialist planning intentions with which the CPB was established by Hein Vos, may have hampered an unbiased reception of its Plans.

Whatever the reason for the small amount of direct influence, Tinbergen and the CPB had an increasing amount of indirect influence. The assessments of the economic prospects and of various policy alternatives slowly received more attention from the ministers responsible for economic policy. This laid bare some differences of opinion among the politicians as well as differences with the assessments and plans of the CPB, but it also uncovered a lot of common ground. The decision of Van den Brink to define the general policy targets in the REA and to instruct the $\mathrm{CPB}$ to prepare a Plan accordingly, was an important step in clarifying the advisory role of the CPB. And it certainly helped to generate real policy discussions in the REA meetings, even though many policy measures suggested by the CPB were put aside. 


\section{More Platforms for Policy Advice}

\subsection{Establishment of the SER and the CEC}

While the CPB could start its work already in 1945, it took much longer to establish another body that was to play an important role in the Dutch social and economic institutional structure. After prolonged discussions, the Social and Economic Council (SER) was established in July 1950. It consisted of fifteen representatives of employers' associations, fifteen representatives of labour unions and fifteen independent experts appointed by the Crown (among whom the President of the Dutch Central Bank and the Director of the CPB). One of its tasks was to advise the government on social and economic policies, on request or by its own initiative (Passenier 1994, p. 111; Camphuis 2009, Chapter 1). Clearly this platform offered new opportunities for Tinbergen and his CPB to influence economic policy.

And soon enough the Dutch economy had to face a challenge that required solid advice. The start of the war in Korea in June 1950 induced substantial hoarding of raw materials and consumer goods. This led to price hikes on international markets and to a serious loss in the terms of trade for most Western economies. Combined with the after-effects of the 1949 devaluation and the planned removal of import restrictions in 1951, for the Netherlands this implied a major loss of real income, a new increase in the balance of payments deficit and higher government expenses on subsidies and defence (Maas 1986, pp. 64-65; Camphuis 2009, p. 85).

The first policy discussion, in August 1950, focussed on prices and wages. The new SER was not ready to offer advice at such short notice, but would do so in due course. The unions called for restrictive price measures and wage increases. In discussions between the Labour Foundation (employers' associations and labour unions) and the government's Committee for Wages and Prices (LPC), it became clear that price measures would not be imposed and that some compensation could be allowed in higher wages (Camphuis 2009, p. 93). As a member of the LPC, Tinbergen likely played a role in these discussions, probably stressing wage restraint in line with his general plea for consumption restraint. By early September, the government decided for a $5 \%$ wage rise, which would only partially offset the increase in prices.

In a memorandum of November 10, 1950, the CPB gave its analysis of the problems and some suggestions for policy response. The Government Commissioner for the European Recovery Plan also prepared a memorandum. Both documents were discussed in the REA on December 5. Views differed again widely, in particular Lieftinck (Finance) and Van den Brink (Economic Affairs) could not agree on new policy measures. Hence the REA decided to install a new committee of officials to report as soon as possible on the balance of payments problems and to offer recommendations for solving them. This Central Economic Committee (CEC) was composed of officials from the relevant ministries, the Dutch Central Bank, the CPB and the office of the Government Commissioner (Maas 1986, pp. 66-68; Passenier 1994, pp. 178-179; Camphuis 2009, pp. 96-97). Within half a year after the SER, this was another new platform for Tinbergen and his CPB. And this one had been wished for 
at the CPB already in 1947, when it became clear how difficult it was to get a fruitful discussion at ministerial level in the REA (Passenier 1994, pp. 177-178).

\subsection{Policy Advice for 1951}

The report of the CEC was prepared by Spierenburg, its Chair, and Tinbergen. Tinbergen already submitted a first version on December 15, 1950. But the substantial measures proposed required quite some time to be approved in the CEC, as its members sought support from their political masters. On January 22, 1951 the CEC delivered its report, with recommendations for curtailing domestic non-defence expenditures by 1.4 billion Guilders, equivalent to some 7 or 8 percent of national income at the time. One of the ways to accomplish this was a net real reduction of wages by $5 \%$. Two days later the Cabinet lost its mandate because of disagreement about the future status of New Guinea. Yet the REA discussed the CEC report in four meetings between January 25 and 31, 1951 and agreed with the key points of the advice. On February 7, 1951, the CEC report was chosen as the basis for the economic program of the new Cabinet which was to bridge the period until the general elections of 1952 (Maas 1986, pp. 68-71; Camphuis 2009, pp. 97-98).

In October 1950 the SER had started to prepare its advice on wage and price policies, as requested by the Cabinet in September. The preparations were done in the Committee on Wages and Prices of the SER (to be distinguished from the government LPC mentioned above). This SER Committee was chaired by Hein Vos, the former minister for the Labour Party. Among the members were Tinbergen, Holtrop (President of the Dutch Central Bank) and De Vries (Chair of the SER). In the first meeting of this Committee, Vos suggested that one could build on previous studies of the issue and that there would not be much to add. This approach met with strong opposition from De Vries, Holtrop and Tinbergen. They gained the support from the other Committee members and soon submitted a paper explaining the challenges that the Dutch economy was facing. Working from the same facts, Vos submitted an alternative paper in December 1950, suggesting that curtailment of domestic expenditures would not be necessary. This suggestion was strongly rejected a few days later in a reaction by Tinbergen, who claimed that consumption would have to be reduced by at least $2.5 \%$, but probably even close to $5 \%$. In January 1951 it became clear that Vos did not get the support from his Committee and he decided to leave the Committee. Tinbergen succeeded him as Chair on January 19, 1951. With strong support from Holtrop and De Vries, he managed to produce a draft advice which was agreed by the SER on February 16, 1951 (published as SER Advisory Report 1951/01). The skilful text that Tinbergen had drafted explicitly avoided taking a political position. It discussed some possible routes to tackle the challenges, and opted for curtailing domestic non-defence expenditures, suggesting some alternative combinations of reductions for consumption and investment. Conditional on the general economic and financial policy that would be chosen by the government, it finally proposed some guidelines for wage and price policy. This analytical approach helped secure unanimous support in the SER (Camphuis 2009, pp. 98-104). 
A more lasting contribution of the Advisory Report 1951/01 was its formulation of the goals of economic policy, due to Tinbergen and Holtrop (Camphuis 2009, p. 108; Passenier 1994, pp. 111, 175). These goals included (i) a high level of real national income; (ii) a low level of unemployment, (iii) a current account deficit on the balance of payments not larger than can be covered by foreign gifts and loans; and (iv) a level of investment which supports a capital stock large enough to employ the available work force. They clearly echo ideas exposed by Tinbergen in his 1944 book, as summarized in Sect. 2.4 above. With some adjustments, these goals would continue to guide the work in the SER until today.

As for the direct influence on actual economic policy, clearly the advice of the CEC at the time was much more important than that of the SER. Indeed, the political decisions had been made on the basis of the CEC report, at a time when the SER had not even finished its work. Tinbergen played a crucial role in assuring that, in broad terms, the advice of the CEC would also gain support from the SER. Not an easy job, considering that the unions had to accept a reduction in consumption. Looking back in 1987-1988, Tinbergen remembered that his good informal relations, e.g. through the Labour Party, had helped. Also, the union leaders clearly had given employment the highest priority and had been ready to accept that this meant a reduction of real wages (De Jong et al. 1988, p. 652). In addition, Camphuis (2009, p. 113) suggests that the main players in the SER may have feared that a dissident advice would have been easily put aside and would not have helped to establish a prominent role for their advisory work. In any case, through the information from Tinbergen and Holtrop, the Cabinet knew that the SER would not come with unpleasant surprises. Indeed, the fact that the SER broadly agreed to the economic policy of the new Cabinet was certainly helpful for the Cabinet and used in the parliamentary debate (Camphuis 2009, pp. 105-107; Passenier 1994, p. 175).

In his 1964 book on Central Planning, Tinbergen takes the history of this policy plan as an example of successful planning. Guessing what might have happened in a less "planned" situation, he suggests that a similar policy would have been carried out. But probably the extent of the plan would have been insufficient because some indirect effects would have been neglected; the acceptance of the trade unions might not have been obtained, with the possibility of strikes and higher wages than desirable and hence more unemployment; and the policy might have started only at a later moment, based on past evidence of the balance of payments instead of on forecasts made half a year ahead (Tinbergen 1964, pp. 55-57).

In June 1951, the new Cabinet asked the SER for a follow-on advice to see whether actual developments called for a change in the policies chosen. Tinbergen again took the lead in preparing a preliminary advice. This advice was issued within a month, but not published. It took much longer to prepare the final version, which was issued in May 1952 when the economic situation had changed considerably. Now the increase in unemployment was the main concern, but the SER did not manage to agree on anything more specific than a call for stimulating employment. Like its preliminary version, this advice was left unpublished and did not have any real influence on policy (Camphuis 2009, pp. 108-112).

The influential work, again, was done in the CEC, in reaction to questions and instructions from the REA. In April 1951, disappointing figures for exports to 
Germany induced a debate on measures to restrain imports without abandoning the recent trade liberalization or harming the growth of the manufacturing industry. The CEC worked on the basis of the CPB forecast for the balance of payments, although the Central Bank thought it was too pessimistic for 1951. In contrast, in June 1951 the REA thought that the CPB was too optimistic for 1952 and it overruled Tinbergen's proposal to loosen the restrictive policies (Maas 1986, pp. 72-76).

\subsection{Looking for a Better Format of the Plan}

In September 1951, the REA discussed the proposal of the CPB to publish a second draft of the Plan 1951. This Plan was the first for which an econometric model was employed. It contained a hypothetical 'forecast' for 1951, based on the assumption that government policies would have continued unchanged from 1950. The CPB then proposed some policy targets: (i) maintain the level of trade liberalization; (ii) avoid, as much as possible, impediments to production and distribution; and (iii) aim for a harmonious allocation of the necessary sacrifices. Next it discussed the ensuing priorities for different policy instruments. And only after this hypothetical exercise, the draft Plan sketched the actual restrictive government policies chosen for 1951, followed by an assessment of the consequences of those policies. The REA strongly objected to this setup and to the implicitly optimistic forecast for a surplus on the balance of payments in the second half of the year. The latter would undermine the support for the restrictive policy that was still in force. With irritation, Tinbergen responded that if also this year the publication of the Plan met with objections, he should receive different instructions. And if, as promised to the Parliament, rapid publication was required, a substantial change in the figures was not feasible. He would not accept the objections to the setup, and pointed out that, on the contrary, the chosen approach led to a clear and favourable presentation of government policy. Realizing that another ban on publication would become a difficult political issue, the REA approved, provided that an introduction would be added pointing out the relative value of the figures (Maas 1986, pp. 81-84; Passenier 1994, pp. 180-181).

Clearly the relation between Tinbergen's CPB and the ministers in the REA was still an uneasy one. In a document about the foundations for the Central Economic Plan 1952, the CPB proposed a completely new line of approach. After a sketch of the economic situation in 1951, it discussed the main determinants that would influence the Dutch economy in 1952. Three categories of determinants were distinguished: (i) external factors, like world market prices, market demand for Dutch exports and the price level of imports; (ii) government policy factors, like government expenditures, tax policies and wage and price policies; and (iii) other factors, like private investments, stock building, population growth and unemployment. Because the CPB considered it very difficult to forecast the exact magnitudes of all these factors, it investigated various possibilities. In particular, it assessed the impact of a change in the external factors, keeping the policy factors constant. And likewise, it assessed the impact 
of a change in government policies, keeping the external factors constant. The stated target of these calculations was to provide useful input for a debate on the policy options that could arise. At the same time, the document drew the conclusion that the promotion of foreign demand in order to raise exports was to offer the best prospects for the balance of payments and for employment. This new approach got a unanimous positive reception in the REA on April 9, 1952. What we now call uncertainty variants and policy variants constitute a toolbox which leaves the policy choice entirely to the politicians (Tinbergen 1952a; Maas 1986, pp. 86-89; Passenier 1994, p. 181; Don 2004).

This marked the start of more fruitful discussions on the annual Plans. The Plan for 1953 distinguished three alternative scenarios, derived from different assumptions about the external factors. While its publication was delayed somewhat because of the consequences of the flood disaster in early February 1953, later years would see a fairly regular publication of the Plans in the Spring of each year (Passenier 1994, p. 141).

\subsection{Policy Advice in 1952-1955}

Early in 1952 it became clear that Tinbergen had been right with his optimism for the balance of payments, while unemployment began to increase as a result of the restrictive policies of 1951 . The CEC was asked to assess what measures were necessary to combat the increase in unemployment. Building on two papers of the CPB, the CEC report of February 5, 1952 contained an assessment of the economic situation and an advice on policy measures, that led the REA to opt for an increase in housebuilding and public works. Though unemployment came down after a peak at the end of February, the CEC suggested further expansionary measures in May 1952. These were agreed in the REA (Maas 1986, pp. 84-86).

The SER was asked for advice on the employment issue in March 1952. It responded with the 'Interim Advice on the Employment Issue' by the end of November 1952 (published later as Advisory Report 1953/03). This advice was very much in line with a contemporary CEC advice, which was likely due to the fact that Tinbergen played an important role in both advisory bodies. The REA discussed both reports together and after long deliberations in three consecutive meetings accepted most of the measures proposed (Camphuis 2009, pp. 112-113).

Only 20 days after the flood disaster of February 1, 1953, the Delta Committee was inaugurated. It was asked to give advice on the execution of plans to increase the safety of the Delta area. Though outside the macroeconomic domain, it is worth mentioning that Tinbergen joined the Committee in March 1954, the sole economist among engineers. With the help of his staff at CPB, he produced a cost-benefit analysis of the Delta Works. In fact, he focused on comparing two alternatives: raising and strengthening dikes all along the waterways versus the more ambitious Delta Works that included the construction of barrier dams (Tinbergen 1954; cf. Bos and Zwaneveld 2017, pp. 22-26). The estimated costs of these alternatives amounted to some 7 and 8 percent of National Income, respectively. Tinbergen's analysis may not 
have been decisive, but it certainly supported the political choice in favour of the Delta Works.

Until 1956 the macroeconomic issues taken up by the SER focussed on wage and price policies. As Chair of the SER Committee on Wages and Prices, Tinbergen played an important role in preparing the relevant Advisory Reports 1953/05, 1954/08 and 1956/01. A special SER committee was formed to prepare the 1955 advice on the system of wage formation, which would result in Advisory Report $1955 / 04$. Tinbergen was appointed as a member, but soon resigned from this committee (Camphuis 2009, p. 149).

Camphuis (2009, pp. 113-134) provides an extensive description of the difficult processes that led to the Advisory Reports 1954/08 and 1956/01 on short term wage policies, in the context of the simultaneous and related processes in the Council of Ministers and in the Labour Foundation. He concludes that these Reports have played only a minor role and at best offered relevant background material for the negotiations in the Labour Foundation and the position taken by the Council of Ministers.

The Advisory Reports 1953/05 and 1955/04 did not focus on short term policies but rather discussed possible changes in the system of wage formation in a longer term perspective. Also on this issue, opinions differed widely. For the first Report, Tinbergen found a way to reach a compromise position. It stated that the then current system (of centrally controlled wage policies) could be continued for another one or 2 years, with adjustments to allow some flexible forms of differentiation. This matched with the feeling in the Council of Ministers that it was still too early to loosen the strong role of the government in the system of wage formation. Soon enough, the disagreement about the principles of a more free system emerged in the preparation of the (divided) second Report. But by then Tinbergen had stepped aside (Camphuis 2009, pp. 134-160).

\subsection{Later Work in the SER}

After Tinbergen left the CPB in 1955, he continued to serve as an independent expert in the SER until 1962. The new CPB director, Fred Polak, took his role in the preparation of Advisory Report 1956/08 on the need for a curtailment of domestic expenditures. Tinbergen participated in the preparation of Advisory Report 1959/02 about the economic policy for 1959 and 1960, in the final stage even temporarily as Chair of the preparatory committee. He disliked the lengthy negotiations and the lack of consensus in the committee, but with the help of the SER Secretariat he managed to draft a text which reflected the various opinions without exposing the large underlying differences (Camphuis 2009, pp. 283, 291). The impact of this advice was mixed. Its main contribution seems to have been that the politicians received useful information about the current economic situation and about the various opinions of the stakeholders in the SER. Some recommendations were followed, others were not (Camphuis 2009, pp. 293-297). Tinbergen seems to have had no particular influence here, except for his successful efforts to produce an advice which properly reflected the variety of opinions in the SER. 


\subsection{Evaluation 1950-1955}

Right from the start, the CEC appears to have been a very fruitful platform for Tinbergen and the CPB to play an influential role in the preparation of economic policy. It was easier for the high ranking officials in the CEC to find common ground in their reports to the REA, reconciling the political preferences of their masters and reflecting the statistical and analytical insights of the $\mathrm{CPB}$. As a leading author of many CEC Reports, Tinbergen certainly had important direct influence here. After his proposals had been amended in the CEC, the Reports proved very influential for the political decisions in the REA.

In comparison, the SER proved less powerful than the CEC. However, being a member of both, Tinbergen was in a position to generate support in the SER for the proposals that were developed in the CEC. Helped by his solid reputation and strong analytical skills, in many instances he proved successful in establishing a consensus in the SER which came close to the results obtained in the CEC. Thus, he helped to create broad support for Dutch macroeconomic policy in the early fifties.

Still, in the REA Tinbergen continued to be met with opposition when he proposed particular policy measures. Ultimately, the ministers responsible for economic policy wanted to make their own assessment of the proper targets and instruments, taking into consideration the relevant uncertainties. Indeed, once the CPB had found a new way to report its findings, which addressed the main uncertainties and explicitly left the choice of policies to the politicians, its Plans were accepted as a useful (and publishable!) input for the policy debate.

\section{Assessment}

\subsection{Direct Influence}

In terms of his direct impact of the choice of policies, the influence of Jan Tinbergen on Dutch macroeconomic policy appears to have been rather small until 1950. Before the war, inspired by the socialist movement, he engaged himself in economic studies to help find proper answers to the problems of that time. Neither his collaboration with Wibaut on worldwide planning, nor his ideas for national planning in 1932 and 1935 had a real impact on economic policies. The analysis of policy alternatives for the Dutch economy that he performed with the first econometric macromodel in 1936 came close, but probably the choice for a devaluation had already been made before his advice was available. In the first years of the CPB, Tinbergen did not get support in the REA for the policies laid down in the consecutive Plans. He remained loyal to the task put upon him by law, but did not receive enough feedback on targets and policies to fulfil it properly. Yet, in this period the Plans were increasingly accepted as a useful basis for the debate on economic policy in the REA. An important step in this direction was the introduction of a new procedure by minister Van den Brink in 1949: now the REA would first agree on the targets of a new Plan, which defined the framework for policy advice by the CPB. However, by and large the policy measures suggested by the CPB continued to be dismissed. 
With the arrival of the SER and the CEC in 1950, the advisory role of Tinbergen and the CPB found more effective platforms (cf. Passenier 1994, p. 182). In the CEC, their advice was discussed on a non-political level and taken on board in a broader collective assessment which had easier access to the political masters. And the SER could benefit from the analyses and insights that Tinbergen brought in from both the CPB experts and the CEC officials. Indeed, it seems that Tinbergen was particularly influential in the CEC as well as in the important SER Committee on Wages and Prices, as leading author of the Reports and soon also Chair of the latter Committee. While it is difficult to assess the direct influence of Tinbergen on the various CEC Reports, it is clear that these Reports were very influential in the actual policy choices made at the political level. In contrast, while we can clearly establish the strong influence of Tinbergen on several SER Reports, the impact of these Reports on actual policy was relatively small. The main influence of Tinbergen was in the fact that he managed to gather support in the SER for the policies that were emerging (or already decided upon) in the CEC and the REA. With this, he is likely to have laid a crucial basis for the success of the SER in later years.

\subsection{Indirect Influence}

It is hard to say what the indirect influence on macroeconomic policy has been of Tinbergen's work before 1945. Certainly, the knowledge of the economic system gained by his studies did influence the later policy debate, as well as the further work of the CPB. His ideas on methods and institutions for the coordination of economic policy were shared by several others and indeed were realized to some extent in the years after war. It was no coincidence that Tinbergen came to be the first director of the CPB.

After the repeated discussions about (consecutive drafts of) the annual Plans which characterized the relations between the CPB and the REA since 1946, the REA meeting of April 1952 marks an important point of convergence. The Central Economic Plan for 1952 followed a completely new line of approach. It distinguished uncertainty variants and policy variants to support an informed discussion about the economic outlook and the relevant policy options. This enabled the two parties in the interaction to live up to effective and compatible role models: the policymaker (the REA) decides on political preferences and chooses the policy that will be implemented (instrument values); the expert (the CPB) decides on the relations between the relevant variables and determines the forecast for all non-instrument variables. Policy variants are a valuable way to inform the policymaker about the consequences of his choices. In addition, it is important that the expert informs the policymaker about the (effects of) forecast uncertainty, possibly in the form of uncertainty variants or alternative scenarios. This approach is still followed today (Don 2001, 2004; cf. Tinbergen 1952b, 1956).

Looking back, Tinbergen himself thinks that the influence of the CPB remained rather small (De Jong et al. 1988, p. 655), observing that policy variants were never really given a try. Surely the direct influence of Tinbergen and the CPB in the REA was still small, but their indirect influence was substantial when the economic 
assessment and the range of relevant policy options were largely accepted by the ministers as the basis for the policy debate. Also in a broader sense, the indirect influence of Tinbergen on Dutch macroeconomic policy has been considerable. The methods and tools that he developed and applied, gained widespread acceptance and continued to be improved upon in later years, particularly in the Netherlands but also elsewhere. His exceptionally bright mind, his great zeal and his drive for good economic policies has been an important force in establishing and guiding the Dutch consensus economy that characterized the second half of the twentieth century.

OpenAccess This article is distributed under the terms of the Creative Commons Attribution 4.0 International License (http://creativecommons.org/licenses/by/4.0/), which permits unrestricted use, distribution, and reproduction in any medium, provided you give appropriate credit to the original author(s) and the source, provide a link to the Creative Commons license, and indicate if changes were made.

\section{References}

Bos, F., \& Zwaneveld, P. (2017). Cost-benefit analysis for flood risk management and water governance in the Netherlands: An overview of one century. The Hague: CPB.

Boumans, M. (1989). De constructie van de samenleving; Tinbergen en de vroege planning. Beleid en Maatschappij, 16(5), 230-245.

Camphuis, W. (2009). Tussen analyse en opportuniteit: de SER als adviseur voor de loon-en prijspolitiek. Amsterdam: Aksant.

Central Planning Bureau. (1956). Scope and methods of the Central Planning Bureau. The Hague: CPB.

Christ, C. F. (1994). The Cowles Commission Contributions to Econometrics at Chicago: 1939-1955. Journal of Economic Literature, 32(1), 30-59.

de Jong, A. H. M., van Paridon, C. W. A. M., \& Passenier, J. (1988). Jan Tinbergen over zijn jaren op het CPB. Economisch Statistische Berichten, 73, 652-662.

de Liagre Böhl, H., Nekkers, J., \& Slot, L. (Eds.). (1981). Nederland industrialiseert!_politieke en ideologiese strijd rondom het naoorlogse industriebeleid 1945-1955. Nijmegen: SUN.

de Man, H. (1934). Voor een Plan van Actie. Brussel: De Wilde Roos.

de Roos, F. (1987). De gave gulden. In A. Knoester (Ed.), Lessen uit het verleden: 125 jaar Vereniging voor de Staathuishoudkunde (pp. 113-131). Leiden: Stenfert Kroese.

de Wolff, P., \& van der Linden, J. T. J. M. (1988). Jan Tinbergen: A quantitative economist. Review of Social Economy, 46(3), 312-325.

Don, F. J. H. (2001). Forecasting in macroeconomics: A practitioner's view. De Economist, 149, 155-175.

Don, F. J. H. (2004). How econometric models help policy makers: Theory and practice. De Economist, 152(2), 177-195.

Duyf, J. M. M. (1993). Een wereld van verschil: het leven en werk van de econoom Jan Tinbergen. Rotterdam: Universiteitsdrukkerij.

Duynstee, F. J. F. M., \& Bosmans, J. (1977). Het Kabinet Schermerhorn-Drees. Assen/Amsterdam: Van Gorcum.

Jolink, A. (2003). Jan Tinbergen. The statistical turn in economics: 1903-1955. Rotterdam: Chimes.

Keuzenkamp, H. (1991). A precursor to Muth: Tinbergen's 1932 model of rational expectations. The Economic Journal, 101(408), 1245-1253.

Knoester, A., \& Wellink, A. H. E. M. (1993). Tinbergen and the Royal Netherlands Economic Association. In A. Knoester \& A. H. E. M. Wellink (Eds.), Tinbergen lectures on economic policy (pp. 9-26). Amsterdam: North-Holland.

Lundberg, E. (1969). Award ceremony speech. NobelPrize.org. Nobel Media AB 2018. Friday Dec 28, 2018. <https://www.nobelprize.org/prizes/economic-sciences/1969/ceremony-speech/>.

Maas, T. H. (1986). Tussen wantrouwen en waardering: het Centraal Plan Bureau en zijn invloed op de economische politiek van vier na-oorlogse kabinetten, 1945-1952. Doctoraalscriptie Sociaal-Economische Geschiedenis. Amsterdam: Vrije Universiteit. 
Magnus, J. R., \& Morgan, M. (1987). The ET interview: Professor J. Tinbergen. Econometric Theory, 3, $117-142$.

Passenier, J. (1994). Van Planning naar Scanning: Een halve eeuw planbureau in Nederland. Groningen: Wolters-Noordhoff.

Pen, J. (2013). Vandaag staat niet alleen-Essays en memoires. Amsterdam: Hollands Maandblad Reeks (No. 111).

SDAP. (1935). Plan van de Arbeid, Rapport van de commissie uit NVV en SDAP. Amsterdam: De Arbeiderspers.

Tinbergen, J. (1932). In hoeverre kan het regelen van den omvang der voortbrenging of van het aanbod van bepaalde goederen door producenten, al dan niet met medewerking van de Overheid, bevorderlijk worden geacht voor de volkswelvaart? In Vereeniging voor de Staathuishoudkunde en de Statistiek, Prae-adviezen 1932 (pp. 48-78). 's-Gravenhage: Martinus Nijhoff.

Tinbergen, J. (1936). Kan hier te lande, al dan niet na overheidsingrijpen, een verbetering van de binnenlandse conjunctuur intreden, ook zonder verbetering van onze exportpositie? Welke lering kan ten aanzien van dit vraagstuk worden getrokken uit de ervaringen van andere landen? In Vereeniging voor de Staathuishoudkunde en de Statistiek, Prae-adviezen 1936 (pp. 62-108). 's-Gravenhage: Martinus Nijhoff.

Tinbergen, J. (1944). De les van dertig jaar-economische ervaringen en mogelijkheden. Amsterdam: Elsevier.

Tinbergen, J. (1946a). Herstelbetalingen. In F. M. Baron van Asbeck, J. Tinbergen \& J. H. W. Verzijl (Eds.), Bouwstof voor de oplossing van Na-Oorlogsche Vraagstukken (pp. 44-53). 's-Gravenhage: Martinus Nijhoff.

Tinbergen, J. (1946b). Letter number C.P.B. 1597 of July 15. In: Nationaal Archief, Den Haag, Ministeries van Algemeene Oorlogvoering van het Koninkrijk (AOK) en van Algemene Zaken (AZ): Kabinet van de Minister-President (KMP), nummer toegang 2.03.01, inventarisnummer 1021.

Tinbergen, J. (1952a). Experiences of central economic planning in the Netherlands (No. 530/D'52). $\mathrm{CPB}$, Mimeo.

Tinbergen, J. (1952b). On the theory of economic policy. Amsterdam: North-Holland.

Tinbergen, J. (1954). De economische balans van het Deltaplan, with some additions reproduced as Bijdrage VI. In Deltacommissie (1961), Rapport Deltacommissie, deel 6 (pp. 61-74). 's-Gravenhage: Staatsdrukkerij- en Uitgeverijbedrijf.

Tinbergen, J. (1956). Economic policy: Principles and design. Amsterdam: North-Holland.

Tinbergen, J. (1959a). An economic policy for 1936. In L. H. Klaassen, L. M. Koyck, \& H. J. Witteveen (Eds.), Jan Tinbergen selected papers (pp. 37-84). Amsterdam: North-Holland.

Tinbergen, J. (1959b). Problems of planning economic policy. UNESCO International Social Science Journal, XI(March), 351-360.

Tinbergen, J. (1964). Central planning. London: Yale University Press.

Tinbergen, J. (1970). De ontwikkeling van de plangedachte. In Centraal Planbureau, 25 jaar Centraal Planbureau (pp. 23-29). 's-Gravenhage: Staatsuitgeverij.

van Cleeff, Ed. (1970). De voorgeschiedenis van het Centraal Planbureau. In Centraal Planbureau, 25 jaar Centraal Planbureau (pp. 7-22). 's-Gravenhage: Staatsuitgeverij.

van der Linden, J. T. J. M. (1985). Economische ontwikkeling en de rol van de overheid-Nederland 1945-1955. Amsterdam: KOBRA.

Wibaut, F. M. (1934). Ordening der Wereldproductie. Haarlem: Tjeenk Willink.

Publisher's Note Springer Nature remains neutral with regard to jurisdictional claims in published maps and institutional affiliations. 